\title{
Laser for the treatment of twin to twin transfusion syndrome ${ }^{1}$
}

\author{
Laser na terapia da síndrome de transfusão feto-fetal
}

\author{
Denise Araújo Lapa Pedreira², Gregório Lorenzo Acácio ${ }^{3}$, Carolina Leite Drummond ${ }^{3}$, Rita de Cássia Sanchez e Oliveira ${ }^{3}$, \\ Alice D‘Agostini Deustch ${ }^{4}$, Wladimir Guimarães Taborda ${ }^{5}$
}

1. Surgical procedures realized at Albert Einstein Hospital. São Paulo - Brazil.

2. Head of Fetal Medicine Team, Albert Einstein Hospital. São Paulo - Brazil.

3. Member of Fetal Medicine Team, Albert Einstein Hospital. São Paulo - Brazil.

4. Head of Neonatal Care Intensive Unit, Albert Einstein Hospital. São Paulo - Brazil.

5. Head of Maternity Unit, Albert Einstein Hospital. São Paulo - Brazil.

\begin{abstract}
Purpose: To report the initial experience in our country with a new technique for twin to twin transfusion syndrome (TTTS) treatment, using laser to coagulate the placental vessels responsible for the twin transfusion during gestation. Methods: Prospective study of eight cases diagnosed with TTTS evaluated in our service from january 2001 to june 2005. Through percutaneous introduction of a 2,0mm diameter fetoscope in the uterine cavity, placental surface vessels where directly visualized. Those identified as responsible for the transfusion were laser coagulated. The procedure combines ultrasonography and fetoscopy, in a so-called sonoendoscopic technique (FETENDO). Results: Among the eight pregnancies evaluated, five cases were submitted to the procedure (10 fetuses). All fetuses survived for at least five weeks after surgery. A total of eight fetuses were born alive and five survived the neonatal period. In a 18 months follow-up after birth, all five are still alive and well and their mean age is now 10,6 months. The total survival rate was 50\% and in three pregnancies, at least one fetus survived. Conclusions: Laser fetoscopy is actually the "gold-standard" treatment of TTTS. Nevertheless is a sophisticated technique that depends of proper training. Our service is the first in our country to offer this therapeutic technique. Our success rate is comparable with the international literature.
\end{abstract}

Key words: Fetofetal Transfusion. Laser Coagulation. Arteriovenous Anastomosis. Twins, Monozygotic. Fetoscopy. Diseases in Twins.

\section{RESUMO}

Objetivo: Nosso objetivo é relatar a experiência inicial no país com uma nova técnica de tratamento para a síndrome de transfusão feto-fetal (STT), onde se utiliza o raio laser para coagulação dos vasos placentários responsáveis pela transfusão entre gêmeos durante a gravidez. Métodos: Estudo prospectivo de 8 casos com diagnóstico de STT avaliados pelo nosso serviço de janeiro de 2001 a junho de 2005. Introduzindo-se um fetoscópio de 2,0 mm de diâmetro na cavidade uterina, por via percutânea, foram diretamente visualizados os vasos da superfície placentária. Aqueles vasos identificados como responsáveis pela transfusão foram coagulados através do laser. O procedimento combina a ultra-sonografia e a fetoscopia, no que se denomina uma abordagem sono-endoscópica (FETENDO). Resultados: Dentre as oito gestações avaliadas, o procedimento foi realizado em cinco casos (10 fetos). Todos os fetos sobreviveram por um período mínimo de cinco semanas após a cirurgia. Na evolução, oito fetos nasceram vivos e cinco sobreviveram ao período neonatal. No seguimento pós-natal de 18 meses, todos os cinco estão vivos e bem, tendo atualmente uma idade média de 10,6 meses. A sobrevida geral foi de $50 \%$, sendo que em três gestações, pelo menos um feto sobreviveu. Conclusões: A fetoscopia com laser é atualmente considerada "gold-standard" no tratamento da STT. No entanto, a técnica é sofisticada e depende de treinamento adequado. Nosso serviço é o primeiro do país a oferecer esta técnica cirúrgica e nossos índices de sucesso se comparam aos índices mundiais.

Descritores: Transfusão Feto-Fetal. Coagulação por Laser. Anastomose Arteriovenosa. Gêmeos Monozigóticos. Fetoscopia. Doenças em Gêmeos.

\section{Introduction}

Twin pregnancies occur in 1 in 96 spontaneously conceived pregnancies ${ }^{1}$. They are classified according chorionicity in monochorionic, when there is a single placental mass and dychorionic when there are two placental mass. One third of twin pregnancies are monochorionic (when assisted reproduction techniques are not used). Twin to twin transfusion syndrome (TTTS) occurs exclusively in this type of pregnancies, in up to $15 \%$ of cases ${ }^{2,3}$. Arteriovenous anastomoses connect the twins circulations, in monochorionic pregnancies. Twin to twin transfusion syndrome happens when a preferential flow occurs in the arteriovenous anastomoses, so one fetus becomes donor 
and the other receptor of an increased blood volume $e^{4,5}$. Donor twin becomes hypovolemic, producing less urine and less amniotic fluid, resulting in oligohydramnios. Receptor twin become hypervolemic, producing more urine and excessive amniotic fluid amount (polyhydramnios). This can lead to complications such as premature delivery, premature rupture of membranes, fetal hydrops and/or death of one or both twins. Prenatal diagnosis relies on ultrasonography, when there is polyhydramnios with full bladder in the receptor and oligohydramnios with empty bladder in the donor twin. Quintero et al. ${ }^{5}$ classified the disease according to its gravity in five stages. When TTTS occurs below 26 weeks fetal mortality can reach $90 \%{ }^{6,7}$. Until early 90th's, many approaches where used in the management of TTTS: selective sacrifice of one twin (feticide), perforation of the inter twin membrane (septostomy) and serial amniodrenage ${ }^{8}$. Nevertheless, none of them effectively treated the underlying physiopathology of the disease. De Lia et al. ${ }^{9}$, proposed an open surgical approach aiming to coagulate the anastomotic vessel using laser, interrupting the transfusion among the twins. Ville et al. ${ }^{10}$, report the first successful case treated with laser using a new less invasive percutaneos approach, starting the utilization of a so called sono-endoscopic technique ${ }^{11}$. The procedure consisted in introducing an optical device in the uterine cavity, guided by ultrasonography, towards the placental surface. The aim was to laser coagulate the placental vessels responsible for the transfusion. Today this procedure is considered the "gold standard" for TTTS. Our service is the first one in the country to offer this therapeutic approach and our aim is to report our initial experience applying this technique.

\section{Methods}

Prospective study of eight TTTS diagnosed cases evaluated from January 2001 to June 2005. The diagnosis was based in the presence of polyhydramnios (larger amniotic fluid pocket above $8 \mathrm{~cm}$, before 20 weeks and above $10 \mathrm{~cm}$, after 20 weeks) with full bladder in the receptor twin, and oligohydramnios (larger amniotic fluid pocket less then $2 \mathrm{~cm}$ ) with an empty bladder, in the donor twin. Laser was accomplished by direct visualization of the placental vessels, by introducing a 3,2 $\mathrm{mm}$ fetoscope in the uterine cavity percutaneously. The communicating vessels where coagulated in the placental surface, interrupting the transfusion.

\section{Surgical procedure}

Maternal sedation with benzodiazepinics was used, combined or not epidural anesthesia. After sterile draping and local skin anesthesia, a 3,2 mm diameter sheet with trocar was introduced in the receptor amniotic cavity. The introduction was ultrasonographically guided, as shown in Figure 1. The trocar was withdrawn and a 2,0 mm diameter fetoscope was introduced through the sheet (Karl Storz Germany). Surface placental vessels crossing the meridian among the cord insertions where directly identified. A 400micra laser fiber was introduced through the sheet's lateral canal and a series of non contact Nd-YAG-laser
(Neodymuim: yttrium-aluminum-garnet) laser shots where performed, using 20-40 watts and 3 seconds pulses (Figure 2).

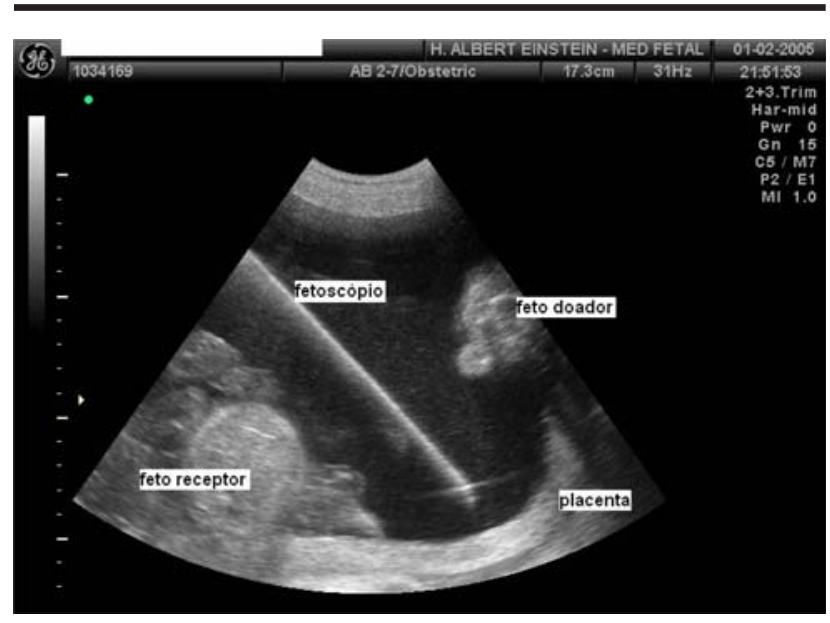

FIGURE 1 - Ultrasonographic image of the fetoscope inside the uterine cavity. The fetoscope is facing the placental surface, also both fetuses can be seen in a tranversal view.

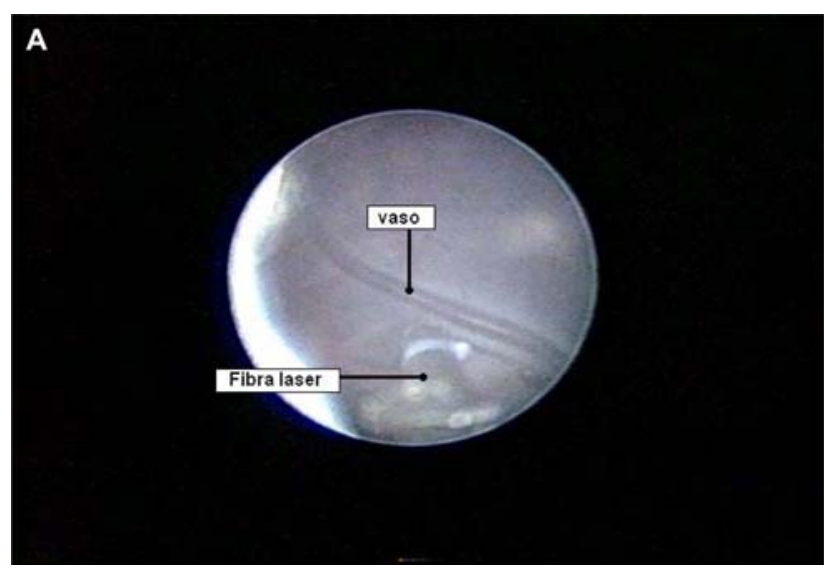

B

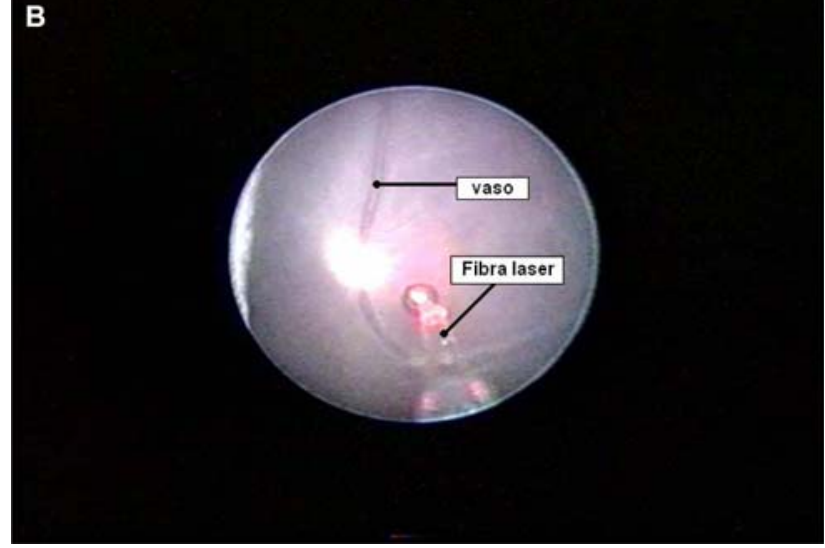

FIGURE 2 - Fetoscopic image, note the placental vessel that will be coagulated and the laser fiber tip, right before (a) and after (b) the laser shot.

The fetoscope was then withdrawn and the excess amniotic fluid in the recipient sac was drained, until the amount of fluid was considered normal. The sheet was also removed and the skin was closed. Fetal wellbeing was 
ultrasonographically evaluated at the end of the procedure. Premature labor was prevented with intravenous betamimetics for 12 hours after the procedure. Another fetal ultrasonographic evaluation was performed before discharge and where sent to ambulatorial control.

\section{Results}

From the total of eight pregnancies evaluated, one patient delivered spontaneously prior to surgery, a second patient did not consent with the procedure and in another case fetal death of the second twin had already occurred by the time of the evaluation. Laser surgery was accomplished in five cases (10 fetuses). The medium gestational age of the procedure was 21,8 weeks and in three cases the placenta had an anterior insertion. All 10 fetuses survived the immediate post operative period. During prenatal followup, both twin fetuses died simultaneously five weeks after surgery. The medium gestational age at delivery was 30,2 weeks. Among the eight fetuses that were born alive, two died prior to 48 hours of life and one case died in the $17^{\circ}$ days (Table 1). At 18 months of postnatal follow-up, the remaining five fetuses that survived the neonatal period are alive and well, aging a medium of 10,6 months. Total survival rate was $50 \%$, and in three pregnancies, at least one fetus survived.

TABLE 1 - Description of the cases submited to fetoscopy for treatment of twin to twin transfusion syndrome.

\begin{tabular}{llllllll}
\hline $\mathbf{N}$ & Stage* & $\begin{array}{l}\text { GA laser } \\
\text { (weeks) }\end{array}$ & $\begin{array}{l}\text { FH } \\
\text { (cm) }\end{array}$ & $\begin{array}{l}\text { GA } \\
\text { delivery } \\
\text { (weeks) }\end{array}$ & $\begin{array}{l}\text { BW D/R } \\
\text { (g) }\end{array}$ & $\begin{array}{l}\text { Follow-up } \\
\text { D/R }\end{array}$ & $\begin{array}{l}\text { Age } \\
\text { (months) }\end{array}$ \\
\hline 1 & Grade III & 21 & 38 & 26 & $640 / 1180$ & Death 3 hol/death 17dol & - \\
2 & Grade III & 24 & 31 & 33 & $1590 / 2690$ & Alive/alive(CHF grade IV) & $18 / 18$ \\
3 & Grade II & 23 & 28 & 32 & $900 / 2140$ & Death 3 dol/alive & 13 \\
4 & Grade III & 22 & 30 & 35 & $1110 / 2630$ & Alive/alive & $1 / 1$ \\
5 & Grade III & 19 & 36 & 25 & $725 / 790$ & Fetal death/fetal death & - \\
\hline
\end{tabular}

* Staging severity according Quintero et al., $1999^{5}$

D/R - donor/recipient

$\mathrm{FH}$ - fundal height

GA - gestational age

BW - birthwheight

$\mathrm{CHF}$ - congestive heart failure

dol - days of life

hol - hours of life

\section{Discussion}

Only after 2004, laser fetoscopy started to be considered the "gold-standard" for TTTS treatment, subsequent to the publication of the first prospective randomized trial comparing fetoscopy to serial amniodrenage $^{12}$. The procedure utilizes a complex sonoendoscopic approach that involves obtaining of an endoscopic image of the interior of the uterine cavity, associate to ultrasonography. Without the aid of ultrasonography, the surgeon would be lost in the uterine cavity due to the small caliber of the fetoscopic lens that reduces greatly the visual field, turning the fetus into a "giant" to be explored. So the surgeon has to combine the two images to reach its goal, this makes previous training even more important for the success in applying this technique. There are no experimental models of TTTS, so the training to identify the vessel to be coagulated can only be realized in humans. Nevertheless, animals can be used in training random vessel coagulation inside the uterine cavity and also in the combination of the two images, endoscopic and ultrasonographic. Our training was realized in one human case under direct supervision by a highly capacitated professor and subsequently in the animal model (Figure 3), the pregnant sheep also, under direct supervision. There are some techniques described to choose which vessels should be coagulated $d^{5,10,13}$, we use the one where the vessels that crosses the meridian between the placental umbilical

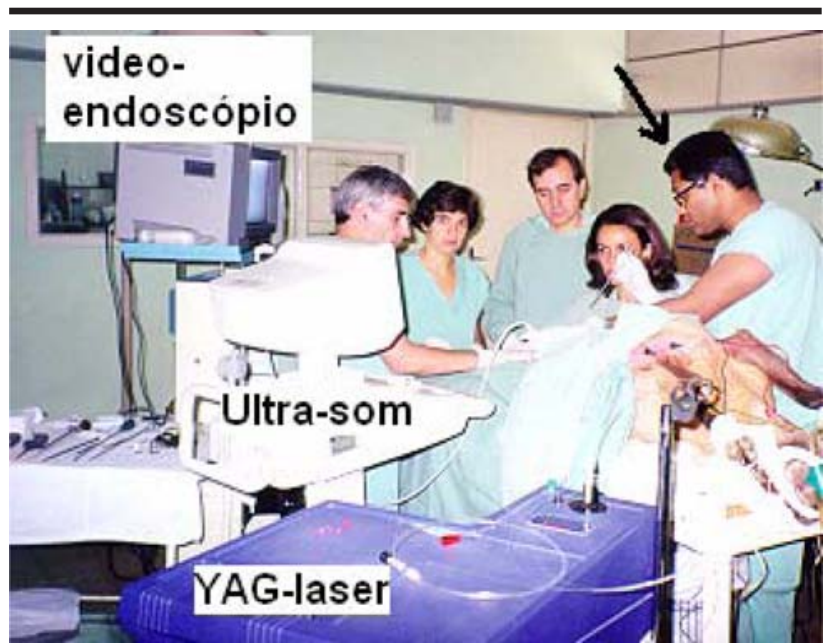

FIGURE 3 - Animal model training during Prof.'s Basky Thilaganathan (arrow) visit to Brazil in 1999 (Experimental surgery laboratory of Instituto Dante Pazzanese de Cardiologia). External aspect of the surgical procedure showing the percutaneous intra-uterine access. Note that the surgeon has to simultaneously deal with the ultrasonographic and videoendoscopic images. 
cord insertions, described by Thilaganathan, et al., ${ }^{13}$. We believe that it better preserves the placental territory of each twin. Although our numbers are still small, this is our initial experience, our general survival rate in a long term follow-up was $50 \%$, this compares to the number found in the international literature that varies from 53 to $56 \%$, $5,12,14,15$. Placentas inserted in the anterior uterine wall are considered a challenge because it makes more difficult to choose the entry point, in order to reach the placenta at a 90 degree angle. In our experience we treated 3 of such cases and apparently this did no alter our success rate. Although the success using this technique increase almost 6 times the chances of survival, the disease is severe and this severity remains even after the surgical procedure. The main risks associated are prematurity the degree or lesion already established up to the time of surgery (for instance the heart failure, present in case 2). Even in the best international experience $^{12}$, death of both twins still occurs in $24 \%$ of cases, despite the intervention. For counseling purposes one of the most indexes used is the chance of taking at least one baby home. This number reaches $70 \%{ }^{12}$ and occurred in 3 out of our 5 cases. To date, laser fetoscopy is the best option for TTTS treatment and we believe adequate training is the key for the success using this technique.

\section{Conclusions}

Laser fetoscopy for Twin-Twin Transfusion Syndrome treatment is a sophisticated technique that requires adequate training. Immediate postoperative numbers of success does not reflects long term success, so postnatal follow-up is essential to evaluate fetal survival. The initial success in the application of the technique in our country compares with the success in international centers.

\section{References}

1. Quigley JK. Monoamniotic twin pregnancy. Am J Obstet Gynecol. 1935;29:345-62.

2. Newton ER. Antepartum care in multiple gestation. Semin Perinatol. 1986;10(1):19-29.

3. Sebire NJ, Snijders RJ, Hughes K, Sepulveda W, Nicolaides $\mathrm{KH}$. The hidden mortality of monochorionic twin pregnancies. Br J Obstet Gynaecol. 1997;104(10):1203-7.

4. Baldwin VJ. Twin transfusion syndrome. Am J Obstet Gynecol. 1990;163(4):1376-7.

5. Quintero RA, Morales WJ, Allen MH, Bornick PW,
Johnson PK, Kruger M. Staging of twin-twin transfusion syndrome. J Perinatol. 1999;19(8):550-5.

6. Taylor MJ, Farquharson D, Cox PM, Fisk NM. Identification of arterio-venous anastomoses in vivo in monochorionic twin pregnancies: preliminary report. Ultrasound Obstet Gynecol. 2000;16(3):218-22.

7. Brennan JN, Diwan RV, Rosen MG, Bellon EM. Fetofetal transfusion syndrome: prenatal ultrasonographic diagnosis. Radiology. 1982;143(2):535-6.

8. Wee LY, Fisk NM. The twin-twin transfusion syndrome. Semin Neonatol. 2002;7(3):187-202.

9. De Lia JE, Cruikshank DP, Keye WR Jr. Fetoscopic neodymium:YAG laser occlusion of placental vessels in severe twin-twin transfusion syndrome. Obstet Gynecol. 1990;75(6):1046-53.

10. Ville Y, Hecher K, Ogg D, Warren R, Nicolaides K. Successful outcome after Nd:YAG laser separation of chorioangiopagus-twins under sonoendoscopic control. Ultrasound Obstet Gynecol. 1992;2(6):429-31.

11. Pedreira DAL Maria RS Perspectivas em cirurgia fetal: abordagem sono-endoscópica. Acta Cir Bras. 1999; 14(3): 144.

12. Senat MV, Deprest J, Boulvain M, Paupe A, Winer N, Ville Y. Endoscopic laser surgery versus serial amnioreduction for severe twin-to-twin transfusion syndrome. N Engl J Med. 2004;351(2):136-44.

13. Thilaganathan B, Gloeb DJ, Sairam S, Tekay A. Sonoendoscopic delineation of the placental vascular equator prior to selective fetoscopic laser ablation in twin-totwin transfusion syndrome. Ultrasound Obstet Gynecol. 2000;16(3):226-9.

14. Ville Y, Hyett J, Hecher K, Nicolaides K. Preliminary experience with endoscopic laser surgery for severe twintwin transfusion syndrome. $\mathrm{N}$ Engl J Med. 1995;332(4):224-7.

15. Zikulnig L, Hecher K, Bregenzer T, Baz E, Hackeloer BJ. Prognostic factors in severe twin-twin transfusion syndrome treated by endoscopic laser surgery. Ultrasound Obstet Gynecol. 1999;14(6):380-7.

\section{Acknowledgements}

We would like to thank Prof. Kypros Nicolaides and Prof. Basky Thilaganathan for thei supervivion in training. To Prof. Dr. Saul Goldenberg, for his support and opportunity. To Dr. Wilson Leite Pedreira Jr for the manuscript review and to Leonardo Lapa Pedreira for the graphic work on the figures.

\section{Correspondence:}

Denise Araújo Lapa Pedreira

Rua Bagé, 163/182

04012-140 São Paulo - SP - Brazil

wdpedreira@uol.com.br
Conflict of interest: none Financial source: none

Received: April 28,2005

Review: May 19,2005

Accepted: June 21,2005

\section{How to cite this article:}

Pedreira DAL, Acácio GL, Drummond CL, Oliveira RCS, Deustch AA, Taborda WG. Laser for the treatment of twin to twin transfusion syndrome. Acta Cir Bras. [serial on the Internet] 2005 Nov-Dec;20(6). Available from URL: http://www.scielo.br/acb 